\title{
Intentziozko irakurketa ozena: lehen urratsak
}

Eneritz A. García-Arriola

Bilboko Irakasleen Unibertsitate Eskola Euskal Herriko Unibertsitatea UPV/EHU

Mikel Iruskieta Quintian

Hizkuntzaren eta Literaturaren Didaktika Saila

Bilboko Irakasleen Unibertsitate Eskola Euskal Herriko Unibertsitatea UPV/EHU

DOI: $10.1387 / \operatorname{tantak.17482}$

GAKO-HITZAK: irakurketa ozena, balio pragmatikoa, intentzioa.

\section{SARRERA}

Ahozko diskurtso asko idatziz prestatzen dira ahoz esateko, batzuetan idatzitakoa nekez irakurtzen da, beste batzuetan, ordea, bat-batekoari tarte gehiago uzten zaio irakurtzen gaudela nabaritu gabe, ahozko kontaketara hurbilduz. Hitzaldiak grabatzeko eta zabaltzeko baliabideak askoren eskura daudenez, gero eta ohitura gehiago dago hitzaldiak eta aurkezpenak grabatzeko eta internet bidez berrerabiltzeko, baita azpitituluak (hainbat hizkuntzetan) jartzeko ere. Gero eta hiztun gehiago grabatzen dira, baita esparru gehiago ere, adibidez, eskolako talde-lanen aurkezpena, online ikastaroetan lanak aurkezteko, norbere ikus-entzunezko kontutxoak sarean argitaratzeko, albistegiak, irratiko albiste txikiak edota kolaborazioak, akademiako hitzaldiak, politikarien mitinak edota herri txiki bateko zinegotziaren jarduna. Horrek dakar hein batean ahozkoa gehiago prestatu beharra eta zenbait kasutan ondo irakurtzeko beharra. Lan honetan hori modu egokian egiteko kontuan hartu beharreko zenbait irizpide azalduko ditugu.

Gure lana kokatzeko, hartzaileari dagokionez, bi irakurketa mota daude: a) Entzuleak garrantzirik ez duen irakurketa. Esaterako: zerbait ikasteko, tresna bat erabiltzen ikasteko, egunkariko berriak, eposta, mezuak, txioak, RSS jarioak edota literatur lan bat gozatzeko. b) Entzuleak garrantzi handia duen irakurketa. Esaterako: eskola edo lan akademikoen 
aurkezpena, ${ }^{1}$ ipuin irakurketa, literatur aurkezpenak (poemak, liburuak, antzerkia), politikako hitzarmenak edota mitinak, hedabideetako jarduna (azpitituludun albistegiak, politikarien mitinak, irratiko albiste laburrak), besteak beste. Irakurketa mota honi irakurketa ozena esango diogu, modu ozenean egiten ez bada, zentzurik ez lukeelako.

Irakurketa dramatizatuaren eta irakurketa ozenaren artean desberdintasunak dauden arren, irakurketa modu esanguratsuan egiten denean, zaila da esaten bien arteko muga non dagoen. Adibidez, irakurketa dramatizatuan igorlea testuari edo pertsonaiari lotuta dago eta irakurketa ozenean, berriz, igorleak pertsonaia guztiak egin behar ditu; beraz, pertsonaiak ezberdintzeko teknika ezberdinak erabili behar dira. Bai batean zein bestean irakurleak gorputz hizkuntza osoaz balia daiteke (besoak mugitu, leku batetik bestera mugitu, altxatu...).

Lan honetan, hain zuzen ere, intentziozko irakurketa ozenaz jardungo dugu azaletik; baina entzulearengan sortu nahi ditugun efektu komunikatiboak nabarmenduz. Horretarako, bi ardatz edo balio ezberdinduko ditugu:

a) Araua edo balio linguistikoa (gramatikala), mezua transmititzeko. Balio hau defektuzko balioa da eta hizkuntza-mailetako (fonologia, morfosintaxia eta lexikoa) hizkuntza formak (maila bakoitza osatzen dituzten unitateak) gramatika- edo estilo-liburuetan definitzen dira. Balio linguistikoaren zuzentasuna gramatikaltasunak neurtzen du. (1a) Adibidea gramatikala denez, euskaraz zuzena dela diogu, baina (1b) Adibidea ez da zuzena, ez-gramatikala delako.

(1) a. Nik pentsatzen dut...

b. ${ }^{*}$ Ni pentsatzen dut...

b) Balio pragmatikoa (araua esplotatzea), efektu komunikatiboak lortzeko. Beste balio hau, pragmatikoa, balio linguistikoak komunikatu ezin duen efektua deskribatzeko darabilgu. ${ }^{2}$ Balio pragmatikoa egokitasun sozialak neurtzen du. ${ }^{3}$ Egokitasun sozial horretan ere badago gramatikaltasuna; hizkuntza bat modu ez-gramatikalean

${ }^{1}$ Lanen aurkezpenetan zenbaitetan irakurri beharreko pasarteak jartzen ditugu, horiek egoki irakurtzeak aurkeztu beharrekoari indarra ematen dio.

2 «Informazio paralinguistikoak gramatikaren arauetatik haratago doaz; izan ere, honelakoetan hiztunak eragin nahi izaten dio solaskideari. Paralinguistikoak gaitasun pragmatikoarekin lotuta agertzen dira [...]». (Gaminde et al., 2014, 115).

${ }^{3}$ Zenbaitek komunikatzeari edo egokitasun sozialari ematen diote garrantzia zuzentasuna alboratuz. Agian, hizkuntzaren jabekuntzako maila baxuetan onargarria izan daiteke murriztapen hori, baina kontuan izan behar da zuzentasun ezaz komunikatzeak egokitasun sozialari ere eragiten diola, balio pragmatikoa neurriz erabiltzen denean, arrakastatsua izango da eta kontrolik gabe erabiltzen denean, ordea, komunikazioan eta norberaren irudiarentzat (egoeraren araberako) ondorio kaltegarriak izan ditzake. 
erabiltzen bada, entzuleak zuzendu egiten du eta askotan forma ezgramatikal hori onartzen ez duela nabarmentzen. Edozelan ere, zenbait kasu berezitan balio pragmatikoa eta balio linguistikoa kontraesankorrak dira; kasu horietan, hain zuzen ere, ikusten da ondoen balio pragmatikoak duen funtzioa komunikazioan.

Demagun, antzerki edota telebistako pertsonaia batek euskaldun berriaren papera egin behar duela, orduan eta soilik orduan sortuko du entzulearengan gramatikak eman ezin dion balio komunikatiboa (euskaldun berria dela) (1b) Adibidea esatean. Horrela, ez du zertan esan euskara ikasten ari dela, erakutsi egin egiten du oraindik ez duela oinarrizko arau gramatikal hori egoki erabiltzen. Horrek sortzen duen efektua entzulearengan bikoitza da: batzuei arrotza egingo zaie eta beste batzuei, agian, hurbilekoa. Balio pragmatikoa, beraz, soilik lortuko da, arau apurketa hori sozialki onargarria denean eta balio linguistikoaz lortu ezin dena lortzen denean. Hori dela eta, entzulea ondo baino hobeto ezagutu behar da, gerta baitaiteke - balio linguistikoan ez bezala - batzuentzat baliogarria dena, ez izatea besteentzat. Eta balio pragmatikoa neurtzean dago besteentzat ondo irakurtzearen egiteko nagusia.

Balio pragmatikoak, gure ustean, irakurketa ozenari aberastasuna dakarkio eta ezaugarri positibo hauek ditu: sinesgarria, egoera errealera egokitua, adierazgarria, zentzuzkoa eta atsegina. Horrelako irakurketa ozenari esaten diogu intentziozko irakurketa ozena. ${ }^{4}$

\section{INTENTZIOZKO IRAKURKETA OZENAREN EZAUGARRIAK}

Intentziozko irakurketa ozena zer den deskribatzeko, irakurketa ozeneko zenbait ezaugarri estandarretan oinarrituko gara. Lan honen asmoa ez da irakurketa ozenaren ezaugarri guztiak zein diren deskribatzea, baizik eta balio linguistikoaren eta pragmatikoaren arteko bereizketa deskribatzea eta horren baliagarritasuna nabarmentzea.

Sanz-Pinyolen (2005) arabera hauek dira hizketan eragiten duten ahotsaren ezaugarriak: artikulazioa, bolumena, abiadura, intonazioa. Orohar, horiek dira irakurketa ozenean ere kontuan hartu behar diren ezaugarri nagusiak eta lan honetan landuko ditugunak.

\footnotetext{
${ }^{4}$ Komunikazioan trebatzen hasteko oinarrizkoa da irakurketa ozena; izan ere, esan beharrekoa argi ez izatea da lehenengo oztopoa komunikazioan. Irakurketa ozenak balio diezaioke ikasleari ahozko arauen zuzentasuna eta zehaztasuna praktikatzeko, emozioekin irakurritakoari zentzu gehiago emateko eta komunikazio estrategiekin entzuleengan efektu zehatzak lortzeko.
} 


\subsection{Bolumena (indarra)}

Gizakiak soinuaren indarrari buruz duen pertzepzioari esaten zaio bolumena. Bolumen egokiz irakurtzeko kontuan hartu behar dira hainbat baldintza eta horietara egokitu behar da: entzule mota, kopurua eta posizioa, oztopo fisikoak (hormak), espazioaren tamaina, bitartekoak (mikrofonoak) eta zarata. Besteentzat zerbait irakurtzen dugunean, entzuleek ez lukete ahalegin berezirik egin behar. Bolumen baxuegiak nekea eragin dezake esaten dena entzun nahian eta bolumen altuegia ez da erosoa (SanzPinyol, 2005). Bolumenak ulermenean eragin dezake, esaterako, hizkuntza bat ikasten ari garenean bolumen altuxeagoa behar dugu, esaten dena hobeto ulertzeko.

Erabilera pragmatikoari dagokionez, bolumen aldaketa hitz edota esaldi garrantzitsuenak nabarmentzeko erabil daiteke (Sanz-Pinyol, 2005).

Marañonek (2010), estiloari dagokionez, monotonia saihestea proposatzen du entzuleek arretaz jarrai dezaten ahozko jarduna. Proposamen hori aplikagarria da irakurketa ozenean; izan ere, bolumenarekin sortutako kontrastedun irakurketa erakargarriago da kontrasterik gabekoa baino. ${ }^{5}$

Horrez gain, (2) Adibidean hitzen bolumena nabarmenduz, galdegaia enfatizatzen da eta, beraz, bolumen aldaketak eginez, gure intentzioa erakusten dugu eta elementuetako bat nabarmentzen dugu besteen gainetik eta, horrela, galdera ezberdinei erantzun diezaiokegu: ${ }^{6}$

(2) Politikariak diru publikoa lapurtu zuen atzo.

a. Nork lapurtu zuen dirua?

b. Zer lapurtu zuen politikariak?

c. Noiz lapurtu zuen politikariak dirua?

Hori erakusteko, esaldi bera hiru modu ezberdinetara grabatu dugu, bolumen aldaketak eginez. Grabaketak PRAAT programarekin (Boersma eta Weenink, 2001) aztertu eta azterketa horren intentsitatearen emaitzak erakutsiko ditugu, hurrengo irudietan. Esaterako 1 Irudiak bolumen aldaketa noiz adierazten duen osagaian (atzo) erakusten du.

Zer galdegaia nabarmentzeko grabaketan, ordea, ikus daiteke intentsitatearen gailurra diru publikoa hitzetan dagoela 2 Irudian.

\footnotetext{
5 Bolumen aldaketekin gauza asko egin daitezke, ez da gure asmoa hemen guztiak aipatzea, baina bai batzuk azpimarratzeko bolumenaren erabilera zein den. Esaterako bolumena handituz, begiradaren laguntzarekin arreta galdu duenari arreta jartzeko eska dakioke eskolan. Bolumena handituz hizkuntza-forma bat nabarmentzen denez, hizkuntza-forma batzuk erakusteko erabil daiteke edo gramatika zuzentzeko erabil daiteke.

${ }^{6}$ Esaldiko gauzarik garrantzitsuena nabarmentzeko intonazioa ere erabiltzen dugunez, zaila izaten da bolumen aldaketarekin ez aldatzea intonazioa. Kontuan izan behar den beste gauza da euskaraz, beste hizkuntza batzuetan ez bezala ez dela hitzez hitz irakurtzen, baizik eta sintagmaka.
} 
Eta 3 Irudian, ordea, bolumenaren balio pragmatikoa erabiliz nork (politikariak) nabarmendu dugu eta PRAATeko intentsitatearen gailurra ere hor dago.

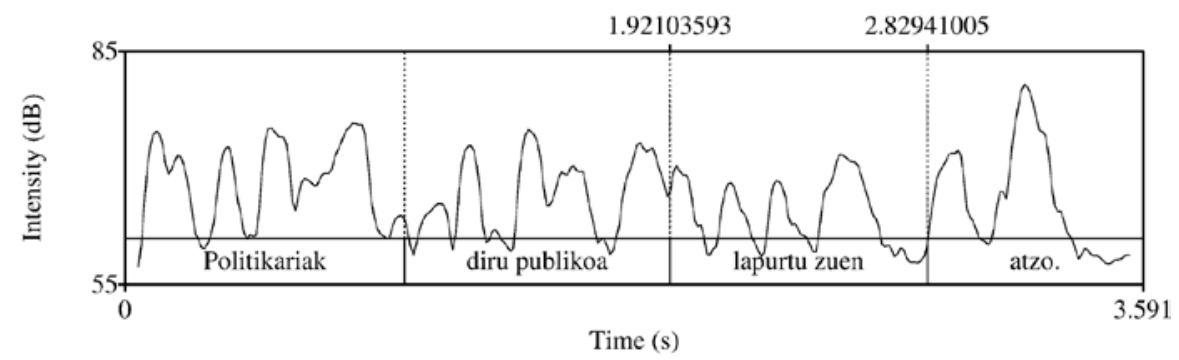

1. irudia

(2) Adibidea, noiz elementua nabarmenduta (balio pragmatikoa)

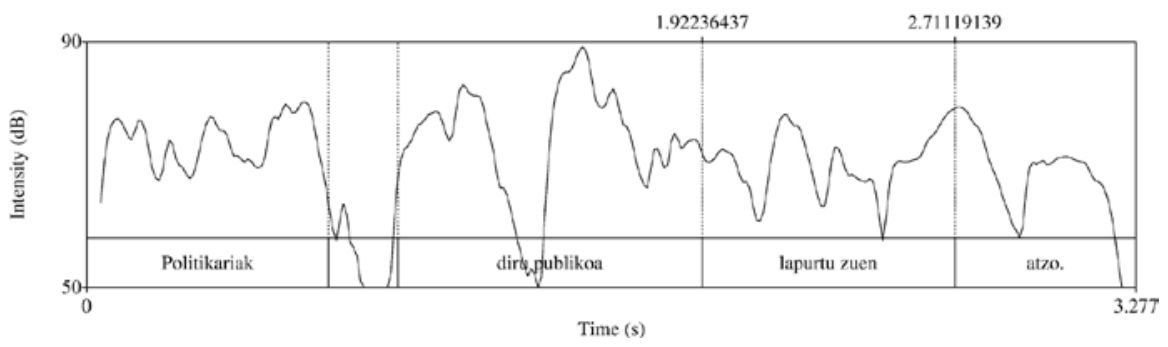

2. irudia

(2) Adibidea galdegaia nabarmendurik (balio linguistikoa)

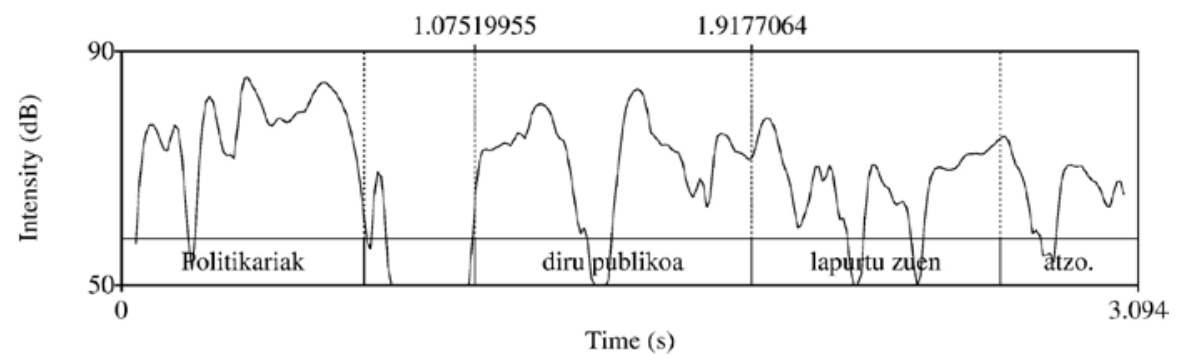

3. irudia

(2) Adibidea nork elementua nabarmendurik (balio pragmatikoa)

Bolumenaren erabilera horrek erakusten du balio pragmatikoa zein den. Ipuin kontaketan balio pragmatikoa asko erabiltzen da; izan ere, ipuin 
kontaketan entzute aitortua eta erreferentziatzat hartu behar den Añorgak (2012) honakoa dio:

Gure lana (kontalariena) da airea ematea hitzari, arnasa, gorputz berria, mugimendua (...) Ondorioz, nahiz eta kontalari bakoitzak ipuin bera kontatu, sekula ez da izango bera. (...) nahiz eta ipuin bakoitzak eduki gorputz identifikagarria, kontalari bakoitzak ematen dio bere azentua, airea, gorputza, arnasa eta begirada partikularra, hots, hizkera. (Añorga, 2012,47)

Ingelesez ulermena errazteko, elementu lexikal garrantzitsuenak ozen esateko joera dago. Antzeko joera hori aurkitu dugu Haur Hezkuntzan irakurtzeko moduko «Txomin txitak» (Denchfield, 2013) ipuinean ere; bada, ipuinean grafikoki adierazten da - letra tamaina handituz, gure adibidean letra larriz - bolumena non igo behar den, hasieran, galdegaiari garrantzia emateko eta, ondoren, irakurraldiari tentsio narratiboa emateko. Ipuin horretako pasarte bat (3) Adibidean erakusten dugu.

(3) Txomin txitak GARI ASKO jaten du. Horregatik du HANDIA eta SENDOA. . MOKOA!

\subsection{Ahoskera}

Ahoskerari dagokionez, Euskara Batuaren Ahoskera Zaindua (EBAZ) ${ }^{7}$ (Euskaltzaindia, 2015) hartuko dugu arautzat, EBAZ baita ahozko hizkuntza estandarraren ahoskeran erreferentziazko arau multzoa. ${ }^{8}$

Arau horretatik honako trabari bilkurak nola ebaki behar diren nabarmendu nahi dugu, erakusten baitu euskaraz sintagmaka irakurri behar dela, bestela esanda, sintagmaka ahoskatu behar dela zenbait egitura: $<z_{-} b$, z_d, z_g > ahoskabe ebaki behar dira: ez da > ezta, ez gara > ezkara eta $<\mathrm{z} \_\mathrm{z}>$ bilkura afrikatu ebaki behar da: ez zara $>$ etzara; ez zenion $>$ etzenion. Baita esan zuen $>$ esantzuen eta eman zion $>$ emantzion. ${ }^{9}$

Erabilera pragmatikoari dagokionez, hitza garrantzitsua dela adierazteko, zenbait soinu (bokalak, dardarkari gogorra -' $r r$ '-, hitz amaierako ergatiboa -' $k$ '...) indartu edota luzatu daitezke.

\footnotetext{
${ }^{7}$ Euskaltzaindiaren arau oso hori hemen irakur daiteke: http://www.euskaltzaindia.eus/ dok/arauak/Araua_0087.pdf.

${ }^{8}$ Euskarazko ebakera hobetzeko Hizkuntzaren Prozesamenduko zenbait tresna proposatu ditu AhoLabek hemen: https://aholab.ehu.es/users/igor/demos.html.

${ }_{9}$ Ohar bedi, arau honi jarraituz eskolan hitzez hitz irakurtzen irakasten dela, baina $-e z$ gero idatzitakoa ezkero esateko erakusten dela; EBAZen aipatutako beste arau guztiei ez zaie garrantzirik ematen.
} 
Bestalde, araua esplotatuz, ahoskera berezia erabiltzen da zenbait ipuinetan pertsonaien jatorria edo izaera zein den nabarmentzeko:

(4) Benetan diotzzuet, adizzkideok: nire familian, zzendagile zzena azzpaldikoa dugu eta gurazzoengandik zzemeengana igaro da behin eta berriro! Nire birraitona ere ozzpe handiko zzendagilea zen! (Lelarge, 2004)

(5) Belagg txagg kiggibilduak iduggi dute - esan zuen Omelette pirata frantsesak (...) (Carranza eta Menendez, 2004, 79)

(6) Inpewio amewikarwak gidawitza duenetik eta euwopako intelligentsia libewal-libewtawio konpwomwzuwik gabekoawen laguntza estimatuawekin nowbanako bewekoi eta gudazaleen gizawtewa goaz. (Etxarte eta Urrutia, 2009, 125)

(7) Jakina! Ondo asko ezautzen du zonalde hoi! (Gallego, 2011, 79)

(8) Ya dakisute ke dauka sekuestrada, no? (Gallego, 2011,79)

(9) Nahiko-a da. Euskal gisarteak al-daketa eskatxen du. Bukatu dira salbatxaile nacionalisten garaiak. Sabinaitor, utxi pakean euskal gisartea. (Gallego, 2011, 168)

(4) Adibidean, pertsonaia eltxoa dela adieratezko, txistukariak ' $z$ ' eta afrikatuak ' $t z$ ' gogor eta intentsitate handiz egiten da eta ahoskerako araua apurtzen da. (5) Adibidean, dardarkariak ' $r$ ' ez dira zuzentasunez ahoskatzen Omelette pirata pertsonaiaren jatorri frantziarra narbarmentzeko: ' $r$ ' ezberdin ahoskatzen duela adierazteko ' $\mathrm{g}$ ' idazten da eta hala irakurri beharko litzateke, efektu komunikatiboa lortzeko. (6) Adibidean, bestalde, amerikarra dela erakusteko ' $r$ ' trabaria ' $w$ ' erdibokalarekin adierazten da. (7) Adibidean, agure euskalduna dela erakusteko ahozkoan ohikoak diren trabari galerekin idazten da: 'eza(g)utzen' edo 'ho(r)i' (8) Adibidean, ordea, ertzain euskaldun berria dela erakusteko gramatika akatsez gain, ahoskerari dagokionez ' $z$ ' txistukaria 's' idazten da, hala irakurtzeko. (9) Adibidean, euskara ez dakien lehendakaria dela adierazi nahi da 'ts' eta ' $t z$ ' guztiak ' $t x$ ' afrikatu berezia eginez, edo euskarazko ' $z$ ' txistukariak gaztelerazko 'c' hortzartekari igurzkariarekin eginez eta hitzen arteko eten ezegokiak (nahiko-a eta al-daketa) ${ }^{10}$ eginez.

Bestalde, nabarmendu nahi dugu balio pragmatikoa erabiltzea ez dela gaur eguneko kontua, esaterako, antzerkigintzan Mirri pailazoa ezaugarritzeko tradiziotik datorren ahoskerako ezaugarriak erabiltzea erabaki zuten:

Eta Mirriri ezarri genion beste erregistro berezia. Ume hizkuntzatik gertu ibiltzea nahi genuen, xelebre izatea ere bai... Horixe bururatu zitzaigun: heldu ez den pertsonaia izatea. Beraz, ahoskera aldetik

10 Azentua ere azken aurreko silaban jarri beharko litzateke hitz horiek irakurtzean, efektua handitzeko. 
ere euskal tradizioan haurrei hitz egiteko manera berezia karikaturizatu egin genuen: bustidurak eta txistukariak nonahi. Arrakasta izan duela ez dago ukatzerik. Tradizioak balio du arrakastarako beraz. (Anzorena, 2010, 19)

\subsection{Intonazioa}

Intonazioa ahozkotasunean ematen den tonu- edo frekuentzia-aldaketa da. Hizkuntza bakoitzak, berez, badauka esaldien intonazioa normaltzat edo ohikotzat hartzen den tonu-aldaketa. Euskara Batuan esaldiaren gorako intonazioa galdegaian eta beheranzko intonazioa aditz nagusia eta gero ematen da. Gaminde et al.ek (2014) prosodiaren bidez transmititzen diren informazio linguistikoen barruan kokatzen dute. Intonazioaren balio fonologikoari esker, esaldi mota nagusiak bereiz daitezke: ${ }^{11}$

- Enuntziatiboen amaieran intonazioa beherantz egiten da.

- Galderetan ere beheranzkoa da intonazioa N-Z galdetzaileakin egiten bada eta bai-ez erantzunezkoa bada, ordea, gorantz bukatzen da.

Bestalde, intonazioak balio du galdegaia aditzaren aurrean ez dagoela nabarmentzeko (balio pragmatikoa), hori erakusteko Eizagirreren (2015) adibidea erabiliko dugu: ${ }^{12}$

(10) Alkateak jakinarazi du aurtengo jaietan ez dela su-festarik egongo.
a. Zeinek?
b. Noiz?
c. Zer?
d. Jakinarazi al du?

Intonazioaren ezberdintasuna argi erakusteko, (10) Adibideko esaldia grabatu dugu eta osagai ezberdinak nabarmendu ditugu intonazioa igoz 4 Irudian ikus daiteke nork horretan nabarmentzen dela intonazioaren gailurra eta 5 Irudian, ordea, intonazioaren gailurra noiz osagaian dago.

Ahozko jardueretan intonazioaren araua betetzeko asmorik ez dagoenean, balio pragmatikoa gauzatzen da, hots, intonazio estrategiak erabiliz, esaldiko galdegaiaren lekuan ez dagoen osagairen bat fokalizatzen da. Intonazioaren balio pragmatikoa lantzeko, ariketa egokia da, esaldiaren egitura sintaktikoa aldatu gabe, esaldiko elementu bakoitzari garrantzia ema-

11 Informazio gehiago izateko jo Elordietaren (2007) lanera edo ikus http://irale. pbworks.com/w/page/14707085/ Intonazioa.

12 Adibide hau eta bestelako adibide interesgarriak entzun eta ikus daitezke honako helbide honetan: http://www.aittu.net/?q=node/165 (1'22»). 


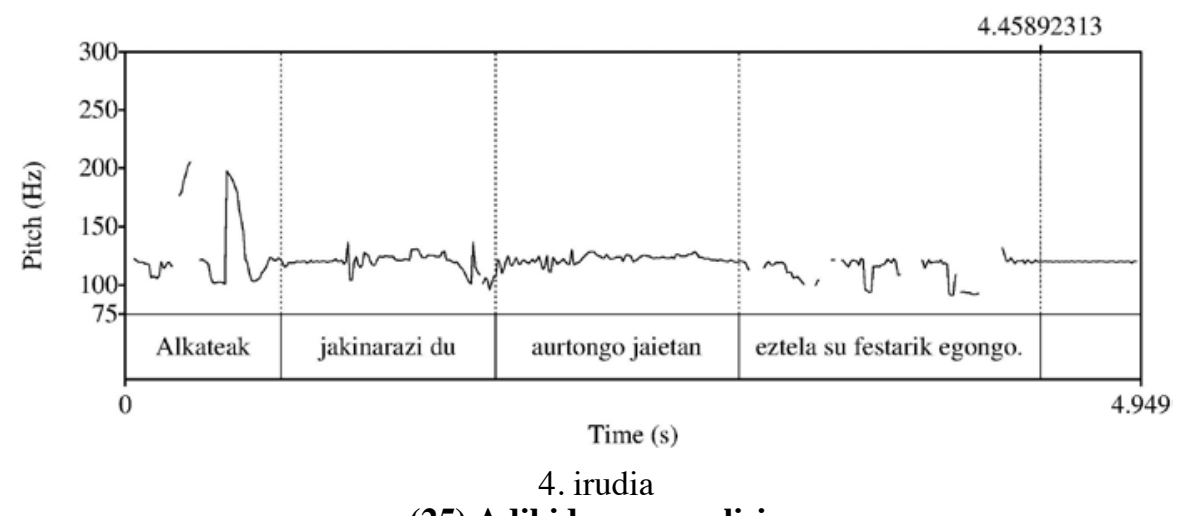

(25) Adibidearen analisia

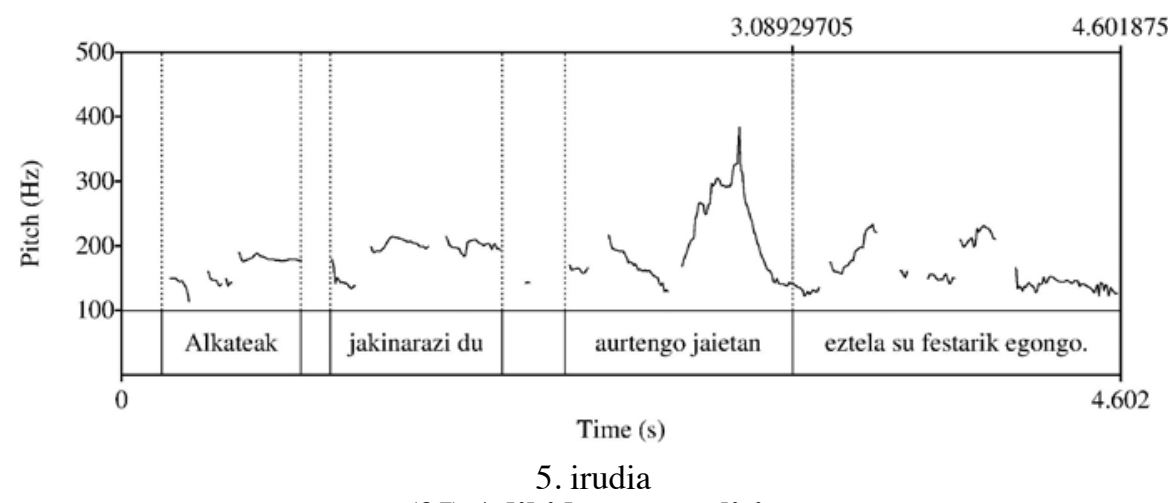

(25) Adibidearen analisia

tea, Eizagirreren (2015) honako beste adibide honetan ere praktika dezake hori, irakurleak:

(11) Amak atzo errieta egin zion umeari.
a. Nork?
b. Noiz?
c. Zer?
d. Egin al zion?
e. Nori?

Intonazioaren balio pragmatikoari dagokionez, intonazioa erabil daiteke irakurtzen ari garena espazioan kokatzeko. Amestoy eta Martinezek (1992) (12) Adibidean goiti esatean intonazioa igotzen du eta behiti esatean intonazioa jaisten du mutilaren bidaia kontalariaren eta entzulearen espazio fisikoan kokatuz. 
(12) Eta holako indar honek mutil gaztea hartu eta ximine zilotik goiti botatzen du, goiti eramaten lainoaren gainera, eta lanoaren gainetik jausten da sasiaren azpira eta sasiaren azpitik goiti berriz, goiti $\nearrow$ goiti $\nearrow$ behiti $\searrow$ behiti $\searrow$ goiti, $\nearrow$ egiten du bide eta heltzen da akelarrera! (Amestoy eta Martinez, 1992)

Bestalde, intonazio-aldaketarekin diskurtsoa erakargarri egiteaz gain, pertsonaiak edo pertsonaien egoerak adieraz daitezke, (13) Adibidean bezalaxe: luma hitza hainbatetan errepikatzen du eta intonazio ezberdina darabil bakoitzean.

(13) Zuk ez dakizu zer diren horiek? A! Axeri! Zerutik erortzen zaizkigun gauza horiek, lumak dira. Lumak!

- Lumak? Lumak?

- Bai lumak! Zeruan festa handi baten prestatzen ari dira eta oiloak, oilaxkoak, ahateak eta antzarak lumatzen dituzte eta horiek botatzen dizkigute. Lumak!!

- Aa!!! Lumak!! (Amestoy eta Martinez, 1992)

Horrez gain, gure ustez intonazio aldakorra zintzotasun ezarekin edota tranparekin lot daiteke pertsonaia gaiztoak ezaugarritzean, hain zuzen ere.

\subsection{Etenak}

Testuaren interpretazio egokirako, irakurleak grafikoki adierazita agertzen diren etenak errespetatu behar ditu eta euskaraz kontuan izan behar da - auzoko beste hizkuntzetan ez bezala - ez dela hitzez hitz irakurtzen, baizik eta sintagmaka; beraz, sintagma barruko elementuen artean ez da etenik egin behar. ${ }^{13} \mathrm{Ez}$ dugu hitzez hitz berba egiten, hots, hitz baten ostean etenak eginez eta irakurketa ozenaren beste ezaugarriak ere (intonazioa, azentua, bolumena, besteak beste) ez dira beti hitzen arabera ahoskatzen. Beraz, euskaraz komeni da ez irakurtzea hitzez hitz, baizik eta sintagmaka.

Horrez gain, etenak kontatu nahi denaren esanahia alda dezake, ${ }^{14}$ hurrengo adibideetan ikus daitekeenez:

13 Adibidean, / ikurra dagoen lekuan eten laburra egiten da, // ikurra dagoenean, aldiz, eten luzea.

${ }^{14}$ Kontuan izan behar da zenbait puntuazio-marka edo sintagma bukaera ez direla zertan eten bidez adierazi, baizik eta intonazio aldaketarekin adierazten direla. Gaminde et al.en (2014) arabera hiru tonu muga daude: goranzkoa, beheranzkoa eta ertaina edo euste tonua eta egoera desberdinetan erabiltzen dira. Beheranzko tonua erabiltzen denean, esaten denaren amaiera adierazten du. Goranzko tonuak, aldiz, amaitu gabe dagoela, esate baterako, zerrendaketa egiten denean. Euste tonuak, bere aldetik, igorleak testua (mezua) egiteko behar duen denborarekin lotuta dago eta goranzko tonuak bezala, amaiera eza adierazten du. 
(14) Umeak jatera goaz!

(15) Umeak, jatera goaz!

(14) Adibidean etenik gabe umeak bazkariaren menua direla adierazten da. (15) Adibidean, aldiz, umeei jateko ordua dela jakinarazten zaie eta umeak hitza dei moduan erabiltzen da. ${ }^{15}$

Hala ere, testuan adierazita dauden etenaldiez gain, irakurleak beste eten batzuk egin behar izaten ditu sintagmetan (16) Adibidean bezala; hauek fisiologikoak (arnasa hartu beharra), semantikoak (esangura), logikoak (kateatzea), psikologikoak (arreta) eta pragmatikoak (estrategia komunikatiboak) izan daitezke (Gaminde et al., 2014).

(16) Atzo / politikari ustel guztiak / atxilotu zituzten. //

Balio pragmatikoari dagokionez, etenak sintagma barruan egin daitezke hitz baten edo hitz horren esanahia nabarmentzeko. Balio pragmatikodun eten horiek hitzen barruan ere egin daitezke araua esplotatuz, hitza silabaka esanez (eta bokalak luzatuz); horrela, hitz hori garrantzitsua dela adierazten da, baita dramatismoa areagotzen ere.

(17) Eta... etorri zen OOO-TSOOO-AAA.

Testua antolatzeko, denbora lor daiteke eten beteak erabiliz ' $a$ ' bokalarekin ('e' ere erabil daiteke) (Gaminde et al., 2014). Bestalde, ahozko testua buruz jakinda ere, bat-batekotasuna erakusteko edo esaten duguna era kritikoan aztertzen ari garela erakusteko ere balio du eten beteak 'am', 'um' edo 'em'. Orobat, eten luzeen bidez, igorleak lor dezake entzuleengan misterioa eta interesa handitzea. Etenaldiak laburrak eta maiztasun handikoak direnean, aldiz, urduritasuna edo larritasuna komunikatu daiteke.

(18) Elurra egingo zuela esan zuten. // Orduan / gizonek / egurrak bildu, / etxean sartu / eta suak piztu, / egin zezala elurra!!! / (Amestoy eta Martinez, 1992)

(19) Eta igo da zeruan, // gero eta gorago, // gero eta gorago //. (Amestoy eta Martinez, 1992)

(20) Ikusi du ere gauza bat bere ondotik pasatzen. / Aizkora bat zen, / Basajaun batek bota ziona. / Eta korrika segitu / Martintxok /. (Amestoy eta Martinez, 1992)

(18) Adibidean, kontaketan puntuazio ikurrek markaturiko etenak baino pausa gehiago egiten dira entzulearengan efektu bat lortuz eta kontaketari erritmo zehatz bat emanez. (19) Adibide honetan, puntuazio laburra dagoen lekuan, eten luzea egiten da; horrela, kontatzen dagoenaren intriga eta era berean, lurraren eta zeruaren arteko distantzia markatzeko erabil-

15 Deikia denez, azentua ere aldatzen da eta erabakigarria da adibide hau ondo ulertzeko. 
tzen du, hau da, soinua ingurune fisikoan kokatzen du. (20) Adibidean, kontalariak puntua dagoen lekuetan eten luzea egin beharrean, eten laburra egiten du; modu honetan, kontatzen dagoen gertaerari azkartasuna eta dramatismoa ematen dio.

Irakurketa ozena egiterakoan, puntuazio ikurrik ez dagoenean, etenaldi laburrak eta luzeak egitea ere posiblea da, entzuleen arreta berenganatzeko edota haiengan efektu edota emozio desberdinak sortarazteko.

(21) Orduan, / Martintxo / bere etxean sartu da, eta laster atera / bota handi batzuk soinean /. (Amestoy eta Martinez, 1992)

(22) Eta gau horretan, / lamiak // hodei zuria // mendi beltz // bihurtu zuen //. (Amestoy eta Martinez, 1992)

(21) Adibidean, puntuazio ikurrik ez dagoen lekuetan eten laburrak egiten dira (Martintxo eta atera hitzen ostean) ahoskatutako azkenengo hitza markatzeko eta aldi berean kontaketari erritmoa emateko.

(22) Adibidean, berriz, puntuazioarekin adierazita ez dauden eten luzeak egiten dira (lamiak, zuria eta beltz hitzen ostean); modu honetan, eten luzeak eginez, entzulearen arreta erakartzen da, balio pragmatikoa erabiliz, esaldiko gertaera etenen bidez gehiago markatzen delako eta entzuleari bere gogoan ekintza jarraitzeko behar duen denbora ematen zaio.

\subsection{Abiadura (erritmoa)}

Aipagarria da irakurketa ozenean abiadura ere kontuan hartu behar dela; izan ere, abiadura handiegian irakurtzeak lapsus kopurua, artikulazio akatsak eta eten desegokiak eragiten ditu, eta horrek ulermena zailtzen du. Beraz, abiadura egokia testuaren tasunek baldintzatuko dute (irakurlearen konpetentziaren arabera). Kontuan hartu behar da abiaduraz ari garenean, erritmoaz eta tempoaz hitz egiten ari garela.

Gaminde et al.en (2014) hitzetan erritmoa hizkuntzaren fonologiaren propietatea da abiadura eta hizketaren denbora-egiturarekiko lotuta dago. Tempoa, ostera, hizketa egiten den baldintzekin eta hiztunaren ezaugarriekin lotuta dago. Abiadura, beraz, pertsona(ia) bakoitzaren bereizgarria da eta emozioek baldintzatzen dute, ez baitugu hizketaldian abiadura bera erabiltzen haserre edo bare-bare gaudenean. Abiadura neutroa zein den zenbakitan ezin zehatz badezakegu ere, bai esan dezakegu ezen, albistegietan edo eskola baten azalpenak ematean testua ondo ulertzeko behar den abiadura erabiltzea komeni dela. ${ }^{16}$

${ }^{16}$ Guk abiadura normala zein den ezarri dugu testuaren silaba/segunduko batez bestekoa erdi-automatikoki kalkulatuz, Agirrezabal et al.ek (2012) garatutako tresna bati esker. 
Abiadura, irakurketan estrategikoki erabiltzeak, hau da, haren balio pragmatikoaz edo estrategia komunikatiboaz baliatzeak, pasartea asko balioesten du, horri erritmoa emanez (garrantzia kenduz: zerrendaketei) edo motelago (garrantzia emanez, karga kontzeptualeko pasarteari) bihurtuz. Abiada emozioekin, jarrerekin edo urduri egotearekin lotzen da, abiadaren erritmoa ahotsaren beste ezaugarrien konbinazioen bidez entzulearengan efektu desberdinak eragiten dituelako. Hizlari edo irakurle ona denak abiada desberdinen erabilera egiten du hartzailearengan eragin nahi dituen emozioen edo kontakizunarekin sorrarazi nahi duen giroaren arabera.

Balio pragmatikoari dagokionez, abiadura ere erabil liteke modu adierazkorrean. Abiadura murrizten denean, pasarteak geldoagoak bilakatzen dira. Horren erakusgarria da (23) Adibidean testuaren izaera nabarmentzen da abiaduraren gelditasunarekin eta etenak ere luzatu egiten direlako. Abiadura azkartzen denean, berriz, pasarteari bizitasuna eta intentsitatea areagotzea bilatzen da. Horren erakusgarri da (24) Adibidea, zeinetan etenen luzera ere murrizten den.

(23) E-txe-ra!!

(24) Arin, arin etxera!

Bestalde, (25) Adibidean mezu garrantzitsuena (definizioa) astiro-astiro esaten du, silaba bakoitza markatuz eta hitzen artean eten luzeak eginez; beste pasartea, ordea, arin-arin esaten du, garrantzia kenduz (informazio ezaguna delako), eta abiadura aldaketa horrek kontrastea sortzen du hasierako mezuak garrantzia duela adieraziz.

(25) Ge-hi-e-nez-ko // a-fo-ro-a // es-pa-zio // kon-tu-a // da. // Errespeta ezazu. / Eusko Jaurlaritza. / Pertsona Helburu.

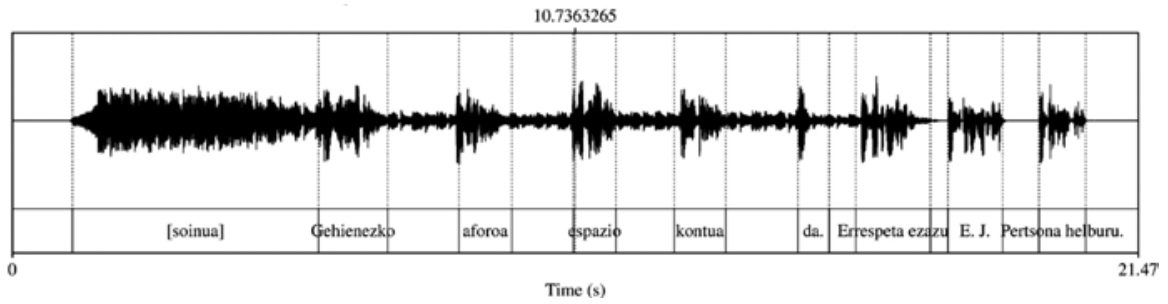

6. irudia

(25) Adibidea: erritmoaren analisia

Abiadura ezberdinak honela neurtzen ditugu: (25) Adibide horretako batez besteko abiada 3,05 silaba segundokoa da (34 silaba 11,13 segundotan). Hasierako pasartea astiro egiten du eta abiada 2,03koa da (16 silaba 
7,88 segundotan) eta abiada azkarrari dagokionez, 4,14koa da (18 silaba 4,35 segundotan).

Horrez gain, emozioekin, jarrerekin edo urduri egotearekin lotzen da (Gaminde et al., 2014). Izan ere, igorleak sortu nahi duen giroaren arabera, hiru abiada nagusi erabil ditzake: i) Arrunta. ii) Astiro edo geldoa. iii) Arina edo azkarra.

Abiada arrunta, abiada arinaren eta geldoaren arteko abiadatzat hartzen da, eta, beraz, neutrotzat hartzen den abiada da. Abiada murrizten denean, entzuleen arreta berenganatzeko asmoarekin, kontakizuna geldoagoa bilakatzea eta misteriotsua eragin lezake. Abiadura azkartzen denean, aldiz, kontakizunari bizitasuna eta intentsitatea ematen zaio.

Horren erakusgarri dira Garcia-Arriolak (2016) Amestoy eta Martinezen (1992) zenbait ipuin aztertu ondorengo 1 Taulako emaitzak. Izan ere, Amestoy kontalariak kontaketa geldoan diharduenean, 1,21 hitz/segunduko ahoskatzen ditu, abiada normaletik 0,26 hitz/segunduko murriztuz. Abiadura arinaren kasuan, berriz, 2,26 hitz/segunduko esaten ditu, bataz besteko abiadura 0,77 hitz/segunduko handituz.

1. taula

Amestoy eta Martinezen (1992) zenbait ipuinetan abiadaren batez bestekoa

\begin{tabular}{l|lccccc}
\hline \multirow{2}{*}{ Ipuina } & & \multirow{2}{*}{ Segundoak } & Hitzak & \multicolumn{2}{c}{ Abiada } \\
\cline { 5 - 7 } & & & & Hitz & Silaba \\
\hline \multirow{3}{*}{ Azeria eta putrea } & Osoa & 240 & 386 & 1,60 & - \\
& A zatia (arin) & 20 & 20 & 1,00 & 6,45 \\
& B zatia (astiro) & 21 & 26 & 1,23 & 3,28 \\
\hline \multirow{3}{*}{ Harri-egilea } & Osoa & 243 & 340 & 1,39 & - \\
& A zatia (arin) & 12 & 26 & 2,16 & 4,83 \\
& B zatia (astiro) & 37 & 44 & 1,18 & 3,31 \\
\hline \multirow{5}{*}{ Martintxo eta basajaunak } & Osoa & 363 & 538 & 1,48 & - \\
& A zatia (arin) & 21 & 26 & 1,23 & 8,47 \\
& B zatia (astiro) & 31 & 69 & 2,22 & 4,00 \\
\hline
\end{tabular}

Garcia-Arriolak (2016) Amestoyk kontatutako ipuin horietan erabiltzen duen abiadura desberdinak erakusteko, ipuin horietako zati adierazgarrienak hautatu ditu. Agirrezabal et al.ek (2012) garatutako tresnaz baliatuz, ipuin zati horien azterketa egin dugu segundo bakoitzean kontalariak egiten dituen silabak kalkulatzeko eta abiadura geldoaren eta arinaren ar- 
teko aldea aztertzeko. Abiadura geldoaren kasuan 3 Taulan ikus daitekeenez, abiadura geldoan 4,59 silaba segundoko esaten ditu. Abiadura arinean, ordea, 2 Taulan ikus daitekeenez, 3,58 silaba segundoko esaten ditu kontalariak.

2. taula

\section{Abiadura arineko ipuin-zatiak}

A zatia

pu.tre.a.ren buz.ta.na u.tzi.ta, a.ze.ri.a lau han.kak 6,45

za.bal-za.ba.la e.ror.tzen da e.ta be.he.re.an i.kus.

(129 silaba 20 segundotan)

ten di.tu ha.rri.ak ten.te ze.ru.a.ri be.gi.ra. or.du.an

a.ze.ri.a ho.nek, oi.hu.ka, ga.rra.si.ka, e.sa.ten di.e:

- be.gi.ra!! al.de e.gin al.de e.gin hor.tik e.ror. tzen bai.naiz!

bai.na ha.rri.ak ez di.ra mu.gi.tu e.ta a.ze.ri.a a.ze.

ri.a ha.rri.en ar.te.an e.ro.ri da ez.kra.txa.tu e.ta

ber.tan hil da!!!!

\begin{aligned} & \hline Harri-egilea A zatia \\ & \hline\end{aligned}

bai.na e.guz.ki.ak be.ro.tzen zu.en, e.rre.tzen zu.en, 4,83

bu.ru.a kix.kail.tzen zi.on. - «zer da hau, e.guz.ki.a (58 silaba 12 segundotan)

ni bai.no in.dar.tsu.a.go a.la? e.guz.ki i.zan be.har

nu.ke!!! e.guz.ki i.zan be.har dut!!!»

Martintxo eta basajaunak

A zatia

— bai! o! o.hoin.txo! ha.rra.pa.tu be.har du.gu!! ha.rra.pa.tu be.har du.gu!!

8,47

(178 silaba 21 segundotan)

or.du.an, ba.sa.jaun gu.zi.ak mar.tin.txo.ren a.tze.

tik ko.rri.ka a.bi.a.tu di.ra. mar.tin.txok, han.txe u.rru.na.go, be.he.ra.go, ko.rri.ka se.gi.tzen du. a.hal du.en be.za.la, be.re bo.ta han.di.ak soi.ne.an. ba.da.ki ba.so.ra hel.tze.an, sal.bu i.zan.go de.la. mo.men.tu ba.te.an, en.tzun di.tu ba.sa.jau.nak hur.bil.tzen! i.ku.si du e.re gau.za bat be.re on.do. tik pa.sa.tzen. aiz.ko.ra bat zen, ba.sa.jaun ba.tek bo.ta zi.o.na. e.ta ko.rri.ka se.gi.tu du mar.tin.txok. ba.sa.jau.nak hur.bil.tzen di.re.la e.ta az.ke.ne.an, bras.ta! 
3. taula

Abiadura geldoko ipuin-zatiak

\begin{tabular}{|c|c|}
\hline Azeria eta putrea & B zatia \\
\hline $\begin{array}{l}\text { e.ta i.go da ze.ru.an, ge.ro e.ta go.ra.go, ge.ro e.ta } \\
\text { go.ra.go. bu.el.ta.ka, bi.ra.ka, goi.ti, goi.ti, i.gan, } \\
\text { i.go, e.ta gain.di.an han.txe ze.ru.ko i.sil.ta.su.ne.an } \\
\text { en.tzu.ten da pu.tre.ak a.ze.ri.a.ri gal.de.gi.ten. }\end{array}$ & $\begin{array}{l}3,28 \\
\text { (69 silaba } 21 \text { segundotan) }\end{array}$ \\
\hline Harri-egilea & B zatia \\
\hline $\begin{array}{l}\text { e.ta gau ho.rre.tan, la.mi.a a.dis.ki.de.ak, e.guz.ki } \\
\text { e.der-e.de.rra ho.dei bi.hur.tu zu.en. ho.dei.a, ze.ru. } \\
\text { an gain.di, ze.ru.a ze.har.ka.tzen i.bi.li zen e.gun } \\
\text { o.so.an. e.ta ge.ro al.de ho.rre.ta.ra hur.bil.du, men. } \\
\text { di i.lun ho.rren in.gu.ru.an i.bi.li, lai.no.ak e.gi.ten, } \\
\text { eu.ri.a, e.lu.rra, txin.go.rra, kaz.ka.ba.rra, ha.rri.a } \\
\text { e.ta guz.ti.ak e.ta men.di.a ez zen mu.gi.tzen! }\end{array}$ & $\begin{array}{l}3,31 \\
\text { (116 silaba } 37 \text { segundotan) }\end{array}$ \\
\hline Martintxo eta basajaunak & B zatia \\
\hline $\begin{array}{l}\text { ha.ran ho.rre.ta.ko he.rri ho.rre.tan, o.gi.rik ez dau. } \\
\text { ka.te, ga.ri.rik ez dau.ka.te. al.ta ba.da.ki.te zer } \\
\text { den, ba.da.ki.te e.re ba.sa.jau.nek, men.di al.de.an, } \\
\text { e.ra.bil.tzen du.te.la. bai.na, no.la e.gin ho.ri lor. } \\
\text { tze.ko, es.ku.ra.tze.ko? ez da.ki.te. be.hin, el.kar. } \\
\text { tu.ak zi.ren he.rri.ko en.pa.ran.tzan he.rri.tar gu.zi. } \\
\text { ak e.ta ez.ta.bai.da.tzen. or.du.an, hur.bil.du zi.tzai. } \\
\text { en he.rri.ko mu.til gaz.te ho.ri: mar.tin.txo. }\end{array}$ & $\begin{array}{l}4,00 \\
\text { (124 silaba } 31 \text { segundotan) }\end{array}$ \\
\hline
\end{tabular}

\subsection{Azentua}

Euskalkitik euskalkira eta eskualdetik eskualdera azentuan eta doinuan aldeak daude eta nabarmenak batzuetan. Azentua batzeko proposamenak izan dira, baina oraindik ez dago araurik euskara baturako eta horrek dakar euskalkidunek (kasurik onenean) euskalkikoa erabiltzea batueraz ari direnean -ikus (26) Adibidea - eta besteek erdaretatik dakartena. Gaztelaniazko azentua euskarara dakartenek gehienbat azkenaurreko silaban - ikus (27) Adibideajartzeko joera dute. Hitzen \% 80k omen du azkenaurreko silaban azentua eta joera hori gailentzen ari da, batez ere lau silabatik gorako hitzetan. ${ }^{17}$

${ }^{17}$ Ikasle askok, esaterako, lanak eta aurkeztu behar dituztenean aditz sintagma moztu eta aditz laguntzailearen azken aurreko silaban jartzen dute azentua ekarriko / dítu eta ez jarri beharden lekuan: ekarríko_ditú. 
(26) Autóbuseán hamázortzí joan dira ikástolará (azentu egokia).

(27) Autobuséan hamazórtzi joan díra ikastólara (azentu arrotza).

Balio linguistikoa zer den jakiteko, hizkuntza ezberdinetako ereduen joerak erakusten ditugu 4 Taulan. Azentua hitzaren (edo sintagmaren) silaba batean jarri behar da. Azentudun silaba bi eratara deskribatu daiteke: i) hasieratik kontatzen hasteko '+' erabiltzen da eta ii) bukaeratik kontatzen hasteko '-' erabiltzen da.

$$
\text { 4. taula }
$$

Euskara, gaztelera eta ingeleraren azentuen joera nagusia sinplifikatuta

\begin{tabular}{l|cc}
\hline \multicolumn{1}{c|}{ Hizkuntzak } & Silabak & Azentu eredua \\
\hline Euskaraz & $\begin{array}{l}\text { X.X́.x.X́ } \\
\text { o.O.o.O }\end{array}$ & $+2-1$ \\
\hline Gaztelaniaz & $\begin{array}{l}\text { X.X.X́.x } \\
\text { o.o.O.o }\end{array}$ & -2 \\
\hline Ingelesez & $\begin{array}{l}\text { X́.x.X.X } \\
\text { o.O.o.O }\end{array}$ & +1 \\
\hline
\end{tabular}

Euskaraz, ordea - ahalik eta sinpleen esanda - , ez dira hitzak soilik azentuatzen, baizik eta sintagmak, besteak beste: bigarren silaba da gogorrena eta azkeneko silaban ere egiten da, suabeago, salbuespenak salbuespen. Izan ere, silaba bakarreko hitzak, normalean, ez dira azentuatzen. Hala ere, ondoko hitzekin elkartzen direnean, elkarketa horretan osatutako hitzaren silaba kopuruaren arabera azentuatzen dira 5 Taularen arabera.

5. taula

Euskal azentua (Zubiri eta Zubiri, 1995)

\begin{tabular}{|c|c|}
\hline Silaba 1 & $\begin{array}{l}X \\
O\end{array}$ \\
\hline 2 silaba & $\begin{array}{l}\text { x.X } \\
0 . O\end{array}$ \\
\hline 3 silaba & $\begin{array}{l}\text { x.X́x. ́x } \\
\text { o.O.O }\end{array}$ \\
\hline 4 silaba & $\begin{array}{l}\text { X.X́ .x.X́ } \\
\text { o.O.o.O }\end{array}$ \\
\hline 5 silaba & $\begin{array}{l}\text { x.X́x.X.X.र́ } \\
\text { o.O.o.o.O }\end{array}$ \\
\hline
\end{tabular}


Gaztelaniaz ez bezala, euskara hizkuntza eranskaria denez, hitzaren egitura morfosintaktikoa (baita esateko modua ere) asko aldatzen da eta, beraz, hitza edota sintagma (perpausa ere bai) era batera edo bestera esateak du garrantzia, azentua ere horren arabera jartzen baita. 6 Taulan euskarazko azentua non jartzen den ikus daiteke. ${ }^{18}$

\section{6. taula}

\section{Euskarazko azentu sistemaren funtzionamendua}

\begin{tabular}{|c|c|c|c|c|c|c|c|}
\hline $\begin{array}{l}\text { e. } \\
\text { o. }\end{array}$ & $\begin{array}{l}\text { txé. } \\
\text { O. }\end{array}$ & $\begin{array}{l}\text { Á } \\
\text { O }\end{array}$ & & & & & $+2-1$ \\
\hline $\begin{array}{l}\text { ba. } \\
\text { o. }\end{array}$ & $\begin{array}{l}\text { sé. } \\
\text { O. }\end{array}$ & $\begin{array}{l}\text { txe. } \\
\text { o }\end{array}$ & $\begin{array}{l}\text { án } \\
\text { O }\end{array}$ & & & & $+2-1$ \\
\hline $\begin{array}{l}\text { e. } \\
\text { o. }\end{array}$ & $\begin{array}{l}\text { txé. } \\
\text { O. }\end{array}$ & $\begin{array}{l}\text { bi. } \\
\text { o. }\end{array}$ & $\begin{array}{l}\text { zi. } \\
\text { o. }\end{array}$ & $\begin{array}{l}\text { tzá } \\
\mathrm{O}\end{array}$ & & & $+2-1$ \\
\hline $\begin{array}{l}\text { e. } \\
\text { o. }\end{array}$ & $\begin{array}{l}\text { txé } \\
\mathrm{O}\end{array}$ & $\begin{array}{l}\text { on. } \\
\text { o. }\end{array}$ & $\begin{array}{l}\text { do. } \\
\text { o. }\end{array}$ & $\begin{array}{l}\text { án } \\
\mathrm{O}\end{array}$ & & & $+2-1$ \\
\hline $\begin{array}{l}\text { e. } \\
\text { o. }\end{array}$ & $\begin{array}{l}\text { txé. } \\
\text { O. }\end{array}$ & $\begin{array}{l}\text { an } \\
0\end{array}$ & $\begin{array}{l}\text { da. } \\
\text { o. }\end{array}$ & $\begin{array}{l}\text { gó } \\
\text { O }\end{array}$ & & & $+2-1$ \\
\hline $\begin{array}{l}\text { e. } \\
\text { o. }\end{array}$ & $\begin{array}{l}\text { txé. } \\
\text { O. }\end{array}$ & $\begin{array}{l}\text { an } \\
\text { o }\end{array}$ & $\begin{array}{l}\text { da. } \\
\text { o. }\end{array}$ & $\begin{array}{l}\text { go } \\
\text { o }\end{array}$ & $\begin{array}{l}\text { e. } \\
\text { o. }\end{array}$ & $\begin{array}{l}\text { tá! } \\
\text { O }\end{array}$ & $+2-1$ \\
\hline $\begin{array}{l}\text { ba. } \\
\text { o. }\end{array}$ & $\begin{array}{l}\text { sé. } \\
\text { O. }\end{array}$ & $\begin{array}{l}\text { txe. } \\
\text { o. }\end{array}$ & $\begin{array}{l}\text { an } \\
0\end{array}$ & $\begin{array}{l}\text { da. } \\
\text { o. }\end{array}$ & & $\begin{array}{ll}\text { e. } & \text { tá! } \\
\text { o. } & \text { O }\end{array}$ & $+2-1$ \\
\hline
\end{tabular}

Euskarazko azentua ondo egiteko, garrantzitsua da bi azentuetako markatuena, lehenengoa, $(+2)$ ondo egitea. ${ }^{19}$

Azentuaren araua asko sinplifikatuta, eta konparagarri eginez, jolaserako helburuz, nolabaiteko ereduak proposa daitezke hizkuntza ezberdine$\tan .{ }^{20}(28)$ Adibidean hiru hizkuntzaren azentu sistemaren joera nagusiak aipatzen ditugu itzulitako esaldi berarentzat: i) Euskarazkoa, (28a) Adibi-

18 Etenek ere azentuan eragiten dute; hortaz, hemen aurkeztutako eredua bat baino ez da, azentuari buruzko informazio gehiagorako ikus Elordieta (2008).

19 Bokatiboak, ordea, azken silaban markatzen dira: Aizu, Enekó! Kontuz, neská! Ea ba, Mikél eta Edurné, zatozte hona; lagunók, gaur nire kontu kafea! (Eizagirre, 2015).

${ }^{20}$ Lan honen helburua ez da azentua deskribatzea, gure helburua da jolasaren bidez azentuaren arauak esplotatzea eta hizkuntzari adierazkortasuna nola eman dakiokeen proposatzea. 
dean, ii) gaztelaniazkoa, (28b) Adibidean eta iii) ingelesezkoa, (28c) Adibidean.

(28) a. Sus.má.ga.rri.á zeu zara! (o.O.o.o.O: $+2-1$ eredua)

b. Usted es el sos.pe.chó.so! (o.o.O.o: -2: eredua)

c. You are the sús.pect! (O.o: +1 eredua)

Joera horiek esplotatuz, azentuaren erabilera pragmatikoari dagokionez, (28a) Adibideko azentua egin beharrean, gaztelerazko azentua imitatzeko (2 eredua) jarrai genezake euskaraz hitz egiterakoan (29b) Adibidean bezala, azken aurreko silaban jarriko genuke azentua. Horrela, euskaraz hitz eginez azentu sistema ezberdinak imita genitzake, ipuinetan, besteak beste, pertsonaiak ezaugarritzeko. Ingelesezko azentua imitatzeko, ordea, +1 eredua (izen eta adjektiboen kasuan) jarrai genezake euskaraz hitz egiterakoan (29b) Adibidean bezala, horrela izen edo adjektiboei lehen silaban jarriko genieke azentua. ${ }^{21}$

(29) a. Sus. ma. ga. rrí. a zeu za ra! (-2)

b. Sús. ma. ga. rri. a zeu za ra! $(+1)$

\subsection{Lapsusak}

Lapsusak hutsegiteak dira, oharkabean egiten direnak. Arrazoi askorengatik gerta daitezke: $i$ ) hizkuntza ezezaguneko hitza, $i i)$ soinu-bilkura edota iii) hitz berriak esatea gehiago kostatzen da, baldin eta ezagutzen dugun hizkuntzatik urrun badaude. Izan ere, irakurleak egitura foniko ezaguna erabiltzeko joera izaten du. Orohar, lapsus mota ezberdinak daude: trabatzeak, bazilazioak eta berregiteak, besteak beste. Testua sarritan irakurtzen bada edota hitz gatazkatsua errepikatzen bada, lapsusak asko murriz daitezke. Hitz zaildun testuak irakurtzea zail egiten da, (30) Adibidea bezalakoak erritmo arruntean eta gelditu gabe ozenki irakurtzen saiatzen bagara, bertako izenak ezezagunak eta egitura silabiko arraroa dute euskaldunontzat.

(30) Adar beldurgarriak: Zeratopsianoek (aurpegi adardunek) adar sorta ikusgarria zuten. Trizeratopsak hiru zituen buru gainean; Pentazeratosak, bost; eta Estirakosauroek, dozena bat! (Elie, 2011,25)

Gauza bera gertatzen zaie euskara ikasten ari direnei edo irakurle ezarituei hitz egitean - baita irakurtzean ere-, erabiltzen ez dituzten egitu-

${ }^{21}$ Balio pragmatikoarekin garrantzia eman diezaiokegu subjektuari honako hitzak indartuz: zeu, usted eta you. 
rak edota esaldiak (edo luzeegiak direnean) lapsusak egiten dituztela. Euskara ikasten ari da (31) Adibidea esan duen pertsona.

(31) Zure zain daudela, argazkiak itzuli nahi... «di...zu...» dizute... «!» dizkizute... «! ! dizkizutela (Fontaneda, 2014)

Lapsusen balio pragmatikoari dagokionez, lapsusak pertsonaia bat sinesgarriago egiteko erabil daitezke, ikasitako diskurtso bati bat-batekotasun itxura emateko ere erabil daitezke edo pertsonaiaren ezintasun/gaixotasun, urduritasuna edota kultura maila baxua adierazteko. Euskaldun batek antzerkian euskaldun berriaren papera joka dezake (31) Adibidea esanez. Bestalde, lapsusaren erabilera pragmatikoa ikus daiteke (32) Adibidean, ume batek pilota bat gaizki bota ondoren esaten duena larritasunez dioela erakusteko 'e, etzu' berregitea erabili delako. ${ }^{22}$

(32) Uu, je, je... barkatu, e, etzu gukin jolastu nahiko, Sabino. (Gallego, 2011, 32)

\subsection{Intentziozko irakurketa egiteko bestelako ardatzak}

Irakurketa ozeneko ezaugarriekin bukatzeko, bestelako ardatzak ere landu daitezke intentziozko irakurketa ozenean: i) Emozioarekin lotutako irakurketari dagozkionak: poza-neutroa-tristura, maitasuna-haserrea, beldurra-segurtasuna, harridura-mesfidantza. Hau tresna automatikoekin ere lortu da, esaterako, AhoTTS tresnak emozio ezberdinekin (neutrala, tristura, poza, haserre, samintasuna, beldurra eta harridura) irakurtzen ditu testuak. ${ }^{23}$ ii) Ikusmenari edo espazioari dagozkionak: adieraz daitezke ahotsarekin irakurketan, pertsonaien forma-tamaina, akats fisiologikoak, tokiak non dauden erakutsi eta aurpegi(er)ak. iii) Entzumenari dagozkionak: ozentasuna-xuxurlatzea-isiltasuna, onomatopeiak, hitzen musikaltasuna, kontakizunaren erritmoa eta bolumena. ${ }^{24}$ iv) Diskurtsoaren antolamenduari eta pragmatikari dagozkionak: koherentzia erlazioak erakustea (azalpena, aurkaritza, birformulazioa) edota pertsonaien ahots ezberdina narratzailea eta pertsonaiak ezberdintzeko.

\section{KOMUNIKAZIO GAITASUNA ETA IRAKURMENA LANTZEKO BALIABIDE INTERESGARRIAK}

Atal honetan, aurretik puntuz-puntu landutako irakurketa ozenaren etenak, azentua, bolumena eta intonazioa biltzen duen adibidea aurkezten

${ }^{22}$ Eten bete gisa ere interpreta liteke 'e' hori eta antzeko helburu komunikatiboa du.

${ }^{23}$ Hemen ikus daiteke: http://aholab.ehu.es/tts/.

${ }^{24}$ Irakurketa-estiloa lantzeko oso gomendagarria da Morenoren (2005) lana. 
dugu. Adibide honen helburua irakurketa ozenaren ezaugarriak praktikaren bidez aztertzeaz gain, balio pragmatikoaren erabilerak testutik ahoz gorako irakurketan dakarren aldaketez ohartzea ere bada.

Horretarako, 7 Taularen analisi markaketa sistema erabili da Nabar Hartzaren ${ }^{25}$ kontakizuna aztertzeko (ikus 8 Taula). Testu horren soinu fitxategia ere badagoenez, irakurketa hori errespetatu badugu ere, zenbait moldaketa egin ditugu balio pragmatikoa ere lantzeko.

7. taula

Analisirako markaketa sistema

\begin{tabular}{lcc}
\hline & Etenak & Azentua \\
\hline Luzea & $/ /$ & Ó \\
Laburra & $/$ & ó \\
\hline & Bolumena & Intonazioa \\
\hline Gora & [LETRA LARRIAK] & $\nearrow$ \\
Behera & & $\searrow$ edo $\downarrow$ \\
\hline
\end{tabular}

8 Taulan ipuin baten testu-zatia jarri dugu (testu originala), eta irakurketa ozena mailaz maila lantzen joateko proposamena egin dugu, lau fase ezberdinetan lantzea proposatzen dugu:

-1 . aldian, testu originala irakurtzea.

- 2. aldian, bolumena eta ahoskera lantzea. Horretarako EBAZeko arau nabermenenak idatzi ditugu eta ozenago esan beharreko hitzak letra larriz jarri ditugu.

- 3. aldian, intonazioa lantzea, noiz gora eta noiz behera egin behar den adieraziz. Horrez gain, ahoskerako markak ere mantendu ditugu.

- 4. aldian, etenak eta azentuak lantzea, sintagmaka. Hemen garrantzitsua da hasi berriek hitz-hitz delako egitura alde batera uztea eta irakurgaia sintagmaka irakurtzea, etenak eta $+2-1$ azentu eredua praktikatzea.

${ }^{25}$ Euskaraz irakurketa esanguratsua egiteko eredu ona da: http://www.nabar.com/eu/. Euskaraz gain, gainera, beste hainbat hizkuntzatan entzun daitezke munduko ipuinak: katalanez, frantsesez, gaztelaniaz eta ingelesez, besteak beste. 
8. taula

Nabar hartzaren ipuin zatia aztertuta eta irakurketa ozen esanguratsua egiteko moldatua

\begin{tabular}{l} 
Nola sortu zen Joantxo, beldurri \\
Testu originala \\
\hline Aspaldi handiko garai haietan, leize \\
zuloan aterpetu behar izan zen hartz bat, \\
artzain borda batetik sobera urrun gabe. \\
Asteak eta asteak ziren lanbroa altxa- \\
tzen ez zela, eta hartzak ez zuen amilde- \\
giren betetik behera amildu nahi. Egon \\
egin behar zuen. Tristerik zegoen, gogo- \\
rra egiten zitzaion bakardade hura. Goiz \\
batez ikusi zuen artzain bordatik emaz- \\
teki bat jalgi zela egur bila.
\end{tabular}

Intonazioa + ahoskera
Etenak + azentua + ahoskera

Aspáldi handiko garai haietàn, / leizé zuloàn / atérpetu behar izantzèn / HARTZ BAT, / artzáin borda batetik / sobéra urrun gabè. // ي́steak eta ásteak zirèn / lánbroa altxàtzen etzelà, // eta hártzak / étzuen amildegiren betetìk beherá amildu nahì. // Egón egin behartzuèn. // TRISTÉRIK zegoèn, // gogórra egiten zitzaiòn / bakárdade hurà. // Góiz batèz / ikúsi zuèn / artzáin bordatìk emázteki bàt / jalgí zelà / egúr bilà. //

Bukatzeko, komunikazio estrategiak ikasteko eta imitatzeko, zenbait proposamen egin nahi ditugu: ${ }^{26}$

- Imitatzeko: i) tradiziozko euskarari lotzeko, Ahotsak proiektuan euskalki askotako soinu-fitxategiak edota bideoak ikus-entzun daitezke eta imitatzen saiatu. Bada, hor dauden ereduak imitatuz zenbait hiztunek adierazkortasuna eta euskalkietako aniztasuna baliatzeko aukera izango dute, ${ }^{27}$ ii) irakurketa dramatizatuko adibide onak ikus-

26 Hauek geuk ezagutzen ditugun proposamenak dira eta ez da hemen gure asmoa zerrendatze luzerik egitea.

27 Ikus hemen Ahotsak proiektua: http://www .ahotsak.eus/. 
teko, Julia Marin irakasle eta antzerki-zuzendariak zuzendutako Durangoko azokakoa, ${ }^{28}$ iii) ipuin kontaralari den Amestoy eta Martinezen (1992) «Bazen behin» ipuin grabaketa eta baita iv) Ikasbileko ${ }^{29}$ irrati nobelak ere.

- Irakurketa ozena prestatzeko honako irakurgaiak ere proposatzen ditugu: i) Irakasleen komunikazio gaitasuna lantzeko Ezeiza et al.en (2009), Garay eta Etxebarriaren (2010) eta Arguelles eta Zelaietaren (2015) lanak eta ii) irakurketa ozenaren ebaluazioa nola egin jakiteko Gaminde et al.en (2004) lana.

\section{ONDORIOAK}

Lan honetan intentziozko irakurketa ozena egiteko bi balio nagusiak deskribatu ditugu, lehendabizi, balio linguistikoa eta balio pragmatikoa zer diren zehaztu dugu eta, ondoren, balio pragmatikoa zeinen baliagarria den erakutsi dugu. Horretarako, euskaraz argitaraturik dauden hainbat adibide erabili ditugu, direla idatzizkoak, direla ahozkoak.

Gure asmoa irakurketa ozena sakontasunez zer den deskribatzea izan ez den arren, intentziozko irakurketa ozeneko zenbait ezaugarriren (bolumena, ahoskera, intonazioa, etenak, abiadura, azentua eta lapsusak) balio linguistikoa eta balio pragmatikoa alderatu ditugu, ezaugarri bakoitzaren baliagarritasuna aurkezteko.

Bolumena da baldintza ezberdinetara (entzule mota, kopurua, zarata, espazioaren tamaina...) egokitzen den soinu indarraren pertzepzioa, eta horretan nahita egindako bariazio aproposak eginez (balio pragmatikoa) irakurketa ozenaren monotonia saihesten, esandako zerbait azpimarratzen eta entzuleen arreta bereganatzen da, irakurketa erakargarriagoa bihurtuz.

Intonazioa da hizkuntza bakoitzak duen berezko tonu- edo frekuentziaaldaketa (maiz bolumenarekin nahasia dago). Ohiko ahozkotasunean naturaltzat hartzen den intonazioa betetzen ez denean, araua esplotatzen da eta entzulearen arreta osagai batean fokalizatzen da.

Abiaduraren bidez ere hartzailearengan efektu eta emozioak (urduritasuna, interesa handitzea...) eragin daitezke, aldaketen bitartez giro desberdinak sortuz. Hala ere, giro horiek garatzeko ezinbestekoa da abiadurarekin batera etenen erabilera egokia egitea. Modu honetan, egoera misteriotsuetan abiadura motela eta eten luzeak egingo ditu igorleak. Aitzitik, entzuleari larritasuna sentiarazteko abiadura handiko eta eten laburreko kontaketa egin beharko du.

28 Ikus hemen https://www.youtube.com/watch?v=lp-Z9Y5StxA.

29 http://www.ikasbil.net. 
Balio pragmatikoa esaten diogu hizkuntzan araua denaren edo naturaltzat hartzen den elementuei dagozkien arauen (balio linguistikoa) esplotazioari edo hausturari, hartzailearen arreta momentu zehatzean bereganatzeko eta entzulearen interesa eta jakin-mina pizteko, irakurritakoaren ohiko ezaugarriren bat edo batzuk aldatuz, intentzioa kontuan izanik.

Etorkizunean, balio pragmatikoan sakondu eta zenbait ezaugarri sakontasunez eta modu sistematikoan garatzeko asmoa dugu, proposamen didaktikoak eginez.

\begin{abstract}
Communicative competence is a topic that has become very popular in recent years. If one wants to communicate or show intentions to get some effects on the hearer, she must practice the pragmatic value of some strategies. We think that reading aloud can be the first step for learners, since knowing what to communicate is most of the times the first difficulty that can be solved easily, if one chooses a good text. Moreover, some communicative intentions are signalled graphically (on text) and with communicative strategies (in audiovisuals). The aim of this paper is to clarify the main phenomena of reading aloud and we show some published examples in a systematic way. These phenomena will be presented by a shallow approach to reach beginner readers, since there are some difficult phenomena that need a more exhaustive explanation. Thus, this paper can be of interest of those beginners who want to improve their intentional reading aloud.
\end{abstract}

Keywords: reading aloud, pragmatic value, intention.

La competencia comunicativa es un campo que cada vez se trabaja más en diferentes disciplinas. Cuando una persona pretende comunicar sus intenciones mediante un texto al oyente o crear en ella un efecto concreto, debe aprender y poner en práctica algunas estrategias pragmáticas. Leer en voz alta puede ser un ejercicio básico para practicar algunas de estas estrategias; de hecho, la primera dificultad - qué contenido comunicar- podría arreglarse fácilmente, si se elige el texto adecuado. Algunas de esas estrategias comunicativas son patentes de forma gráfica (en ciertos géneros textuales) o mediante estrategias comunicativas (en el caso de los audiovisuales). El objetivo principal de este trabajo es aclarar cuáles son los principales conceptos para una lectura intencional en voz alta y mostrar algunos ejem- 
plos publicados de forma sistemática. La descripción de estos conceptos se hace de un modo superficial, para que sea accesible a cualquier persona; ya que, en muchos casos se necesita una descripción más detallada de muchos de los conceptos que presentamos. Pensamos que nuestro trabajo puede ser interesante para aquellas personas que deseen empezar a preparar la lectura intencional en voz alta.

Palabras clave: leer en voz alta, valor pragmático, intención.

La compétence communicative est un domaine qui suscite de plus en plus d'intérêt dans différentes disciplines. Lorsqu'une personne désire de communiquer un message, si elle désire communiquer les intentions de son message aux récepteurs et créer un effet sur eux, elle doit faire usage de stratégies pragmatiques. La lecture à voix haute est un exercice formidable pour mettre en pratique ces stratégies; en effet, la principale difficulté -quel contenu transmettre- pourrait être facilement dépassée en choisissant le texte le plus approprié. En outre, dans certains textes les intentions communicatives s'expriment de façon graphique (lorsqu'il s'agit de textes) et par le biais de stratégies prosodiques (dans le cas de l'audiovisuel). Le principal objectif de ce travail est de préciser quels sont les concepts principaux nécessaires à la lecture à voix haute pertinente et de montrer quelques exemples publiés. La description de ces notions est faite de manière à ce qu'elles soient accessibles à tous; nous sommes conscients que les concepts que nous présentons nécessiteraient une explication plus précise. Par conséquent, notre travail peut convenir à ceux qui veulent commencer à s'exercer à la lecture à voix haute.

Mots-clé: lire à haute voix, la valeur pragmatique, l'intention.

\section{ERREFERENTZIAK}

Agirrezabal, M., Alegria, I., Arrieta, B., eta Hulden, M. (2012). Finite-state technology in a verse-making tool. In FSMNLP, 35-39.

Amestoy, K., eta Martinez, B. (1992). Behin bazen. Donostia: Elkar.

Anzorena, J.I. (2010). ESKARA LA KAKATUA? Ahozkotasuna eta aditasuna. In Ahoa bete hots: Ahozkotasuna kulturan, eguneroko jardun berezituetan eta haur munduan, 11-22. Mintzola.

Arguelles, G., eta Zelaieta, E. (2015). Ahozko adierazpena eta dramatizazioa haur hezkuntzako irakasleen baliabide. Tantak, 27(1), 87-105.

Añorga, P. (2012). Kontalariaren jarrera eta hizkuntz egokitzapena haurrei kontatzerakoan. In Ahoa bete hots: Euskalkiak, batua eta erregistroa ahozko kultur sorkuntzan, 43-57. Mintzola. 
Boersma, P., eta Weenink, D. (2001). Praat, a system for doing phonetics by computer. Glot international 5, 341-345.

Carranza, M., eta Menendez, M. (2004). Pirata maltzurren ipuinak. Donostia: Ttarttalo.

Denchfield, N. (2013). Txomin txitak. Bilbo: Ikasmina.

Eizagirre, P. (2015). Jendaurreko irakurketa. http://aittu.net/. Accessed: 2015-0930 .

Elie, M. (2011). Dinosauroen garaian. Donostia: Ttarttalo.

Elordieta, G. (2007). A constraint-based analysis of the intonational realization of focus in northern bizkaian basque. Tones and tunes, 1, 199-232.

- (2008). Euskal azentu eta intonazioari buruzko ikerketa: status quaestionis. In Koldo Mitxelena Katedraren II. Biltzarra, 389-428.

Etxarte, H., eta Urrutia, A.M. (2009). Ihes ederra. Irun: Alberdaina.

Euskaltzaindia (2015). Euskara batuaren ahoskera zaindua (EBAZ). http://www. euskaltzaindia. eus/dok/arauak/Araua_0087.pdf. Accessed: 2015-09-30.

Ezeiza, J., Aldezabal, I., Elordui, A., Zabala, I., Ugarteburu, I., eta Elosegi, K. (2009). PREST. Unibertsitateko komunikaziorako gaitasunen eskuliburua. Leioa: UPV/EHU.

Fontaneda, G. (2014). Ahozko hizkera arrunta errazteko proposamena. http://alea. eus/ images/stories/ahozko-hizkera-arrunta-errazteko-proposamena.pdf. Accessed: 2016-06-07.

Gallego, P. (2011). Xabinaitorren balentriak. Pololoak 3: Atxeritoko balada (the ballad of Atxerito). Donostia: Elkar.

Gaminde, I., Aurrekoetxea, G., Etxebarria, A., Garay, U., eta Romero, A. (2014). Ahoskera lantzeko argibideak eta jarduerak. Laguntzarako materiala: teoria eta praktika. Bilbo: UPV/EHU.

-, Goikoetxea, U., Barrutia, E., Eizagirre, E., Goikoetxea, J.L, Pérez, K., eta Unamuno, M. (2004). Irakurketa ozena ebaluatzeko irizpideak Bizkaian. Amorebieta: Mendebaldeko Kultura Alkartea Izaro Bilduma III.

Garay, U., eta Etxebarria, A. (2010). Irakasleen komunikazio-gaitasuna: hausnarketarako gaia. Uztaro: giza eta gizarte-zientzien aldizkaria, 39-48.

Garcia-Arriola, E.A. (2016). Ahozkotasunaren balio pragmatikoa ipuin kontaketan: Koldo Amestoy ipuin kontalariaren zenbait ipuinen azterketa. Haur Hezkuntzako Gradu Amaierako Lana. UPV/EHU.

Lelarge, F. (2004). Larrialdiak animalien ospitalean. Donostia: Ttarttalo.

Marañon, M. (2010). Jendaurrean hitz egitea: Traketsetik abilera. Madril: Oberon.

Moreno, V. (2005). Ikasleak irakurzaletzen ahotsa, sentimendua eta sormena erabiliz. Nafarroa: Blitz.

Sanz-Pinyol, G. (2005). Comunicación efectiva en el aula: Técnicas de expresión oral para docentes. Bartzelona: Grao.

Zubiri, E., eta Zubiri, I. (1995). Euskal gramatika osoa. Bilbo: Ikasbook. 